\title{
YHWH está em litígio com Israel: um estudo exegético de Os 4,1-3
}

Orientador: Leonardo Agostini Fernandes

Mestrando: Lucio Nicoletto

Área de Concentração: Teologia Bíblica

Linha de Pesquisa: Análise e Interpretação de Textos do Antigo e Novo Testamento

Na primeira parte do livro de Oseias (Os 1-3) descreve-se a experiência matrimonial do profeta Oseias e o significado que essa experiência (casamento, traição, afastamento e reconciliação) tem como revelação o amor de YHWH para Israel. Na segunda parte do livro (cf. Os 4-11) foram coletados todos os diferentes oráculos atribuídos ao profeta Oséias, que giram em torno do tema do julgamento sobre Israel e a promessa de salvação e perdão.

É possível considerar Os 4,1-3 como que um portal de ingresso desta segunda parte do livro; deixa-se a linguagem alegórica (casamento, prostituição e adultério) e diretamente apresenta-se a queixa sobre a violação do pacto com YHWH. As acusações de suas palavras são dirigidas contra o povo e, mais adiante, contra a classe sacerdotal, os líderes, a família governante e ao rei.

As palavras de Os 4,1-3 convocam os filhos de Israel a um ריב, "litígio", no qual o profeta, em nome de YHWH, denuncia a ruptura da aliança. No meio do "processo judiciário" emerge uma acusação fundamental: a falta de

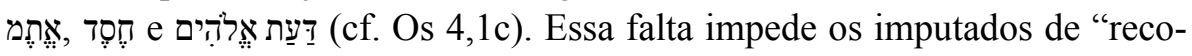
nhecer" as obras de YHWH, Deus de Israel (criação e libertação) e a consequente adesão a um estilo de vida em que estão envolvidas tanto as relações comunitárias bem como as relações com a criação.

Palavras-chave: Antigo Testamento. Literatura Profética. Livro de Oséias. 